\title{
PHYTOPLANKTON STANDING CROP AND SPECIES DIVERSTIY IN RELATION TO SOME WATER CFARACTERISTICS OF SUEZ BAY (RED SEA), EGYPT.
}

\author{
Mohamed Z. Nassar and Mohamed A. Hamed \\ National Institute of Oceanography and Fisheries, \\ Suez and Aqaba Gulfs Branch, Egypt.
}

Key words: phytoplankton, nutrients, Suez Bay.

\section{ABSTRACT}

Dhytoplankton standing crop and species composition in Suez Bay P were studied and discussed in relation to the environmental physico-chemical parameters during 2002-2003. A total of 80 species and varieties were recorded and identified at the selected stations of the bay: Of them 47 species and 29 genera of diatoms; 19 species and 11 genera of dinoflagellates; seven species of cyanophytes within four genera; six species of chlorophytes among four genera and one species of chrysophytes. Two main phytoplankton peaks were recorded during spring and autumn seasons (average of 15,676 and 15,376 unit. $L^{-1}$ respectively). The diatom species responsible of these peaks were, Nitzschia pungens var. atlantica, Asterionella japonica, Skeletonema costatum, Chaetoceros decipiens and Gyrosigma attenuatum. The species diversity showed a minimum value at the sewage treating company ( $\mathrm{ABB}$ station) ranging from $2.17-3.36$ nats. While, the highest diversity values were recorded at the unpolluted station, Aiyoon Mousa (VI) and varied from 2.74-3.61 nats. The results revealed regional and seasonal inverse correlation between diversity and phytoplankton standing crop in Suez Bay and it is regarded as a pollution habitat.

The results of $N: P$ ratio indicated that Suez Bay is generally P-limited, mainly due to the high load of nitrogenous compounds specially ammonia, which formed about $60.71 \%$ of the total inorganic nitrogen, followed by nitrate (33.7\%) and nitrite $(5.57 \%)$. Dissolved inorganic phosphate recorded with annual average of 0.98 $\mu \mathrm{mol} . \mathrm{L}^{-1}$. Generally, the level of nutrient salts indicated that Suez Bay is in the eutrophic state. 


\section{INTRODUCTION}

The Suez Bay (Fig.1) is a shallow extension of Suez Gulf at its northern part. The average length along its major axis is about 13.2 $\mathrm{Km}$. Its average width along the minor axis is about $8.8 \mathrm{Km}$. The bay is connected to Suez Gulf through the south-eastern side and connected to Suez Canal by dredged channel of about $16 \mathrm{~m}$ depth through the north-eastern side. The bay is subjected to different sources of pollution. The first and dangerous one is the oil effluents that discharge from industrial complex south of Suez, which includes the oil refineries, El-Nasr and Suez Petroleum Companies. The second pollution source is the sewage of Suez City, which discharges into the bay. This sewage is recently treated by a treating company namely, ABB from 1994 till now.

The aim of this work is to evaluate the phytoplankton standing crop and diversity of the bay as a result of treating the sewage effluents of Suez City by $\mathrm{ABB}$ company. In addition to study the most physico-chemical parameters helping to define the bay water quality as a nutritive medium for phytoplankton production.

\section{MATERIALS AND METHODS}

Water and phytoplankton samples were collected seasonally through spring, summer and autumn of 2002 and winter, 2003. Six stations were chosen covering different ecological habitats of Suez Bay, namely, Port-Tawfik (I), EL-Zaitia (II), AL-Kabanon (III), ABB company (IV), Adabyia (V) and Aiyoon Mousa (VI) as presented in Fig.1. The former five stations are situated in the northwestern side of the bay, which is subjected to oil effluents and sewage of the Suez City. While station VI is located in the eastern direction of the bay, which is relatively far from the pollution sources and it could be considered as a control for the other sampling stations.

Water temperature was measured by using a simple pocket thermometer graduated to $0.1^{\circ} \mathrm{C}$. The $\mathrm{pH}$ value of water samples was measured in situ using a pocket $\mathrm{pH}$ meter model Orion 210 . The salinity of water was measured in the laboratory by using inductive salinometer (S.C.T. meter). Dissolved oxygen determination was carried out according to Winkler's method as described in APHA (1995). The biological oxygen demand (BOD) and chemical oxygen demand (COD) were determined according to the method reported in APHA (1989). Nutrient salts $\left(\mathrm{NO}_{3}, \mathrm{NO}_{2}, \mathrm{NH}_{4}, \mathrm{PO}_{4}\right.$ and $\left.\mathrm{SiO}_{4}\right)$ were 
determined spectrophotometrically according to the methods described by Strickland and Parsons (1968). Results of nutrients are expressed as $\mu$ mol. $\mathrm{L}^{-1}$.

Phytoplankton standing crop was determined by sedimentation method (Utermohl, 1936) and its magnitude is expressed in units per liter. For identification of the algal taxa, the following references were consulted; Peragallo and Peragallo (1908), Ghazzawi (1939), Cupp (1943), Bourrelly (1968) and Bold and Wynne (1978) for diatoms and silicoflagellates. Ferguson Wood (1968) for dinoflagellates. El-Nayal (1935), Huber-Pestaluzzi (1938) and Prescott (1962) for blue-green algae and Stewart and Mattox (1975) for green algae.

Diversity index was estimated on the computer according to the equation of Shannon \& Weaver (1963) and expressed as nats. The correlation coefficient (r) was calculated between the total phytoplankton standing crop and some environmental parameters on the calculator.

\section{RESULTS AND DISCUSSION}

\section{Physico-chemical conditions}

\section{1) Temperature}

A limited variation in surface water temperature of the Suez Bay was observed and mainly depend on the sampling time. In general, the seasonal temperature variations follow those of the prevailing climate conditions. During this investigation, the mean water temperature ranged between a minimum of $17.33^{\circ} \mathrm{C}$ during winter (2003) and a maximum of $28.33{ }^{\circ} \mathrm{C}$ during summer (2002). The dinoflagellates and blue-green algae showed their maximum flourishing during spring, which was associated with relatively high temperature $\left(21-22.5^{\circ} \mathrm{C}\right)$. These results are in accordance with that obtained by Ibrahim (1988) in Foul Bay of the Red Sea. Ceratium fusus of dinoflagellates was dominant in summer (August) at surface water temperature of $28-29{ }^{\circ} \mathrm{C}$. In relation to eutrophication, temperature seems to have pronounced effect on the rate of phytoplankton photosynthesis as well as periodicity and abundance of phytoplankton species (Behrendt, 1990; Kobbia et al., 1990 and Abdallah et al., 1995a).

\section{2) pH value}

The $\mathrm{pH}$ value of water is controlled by the dissolved oxygen, water temperature, sewage discharge, decomposition of organic 
matter and photosynthetic activities. It lies in the alkaline side and varied within a narrow range (8.31-8.59) with annual average of 8.45 (Table 1). The $\mathrm{pH}$ values are relatively high as compared with that previously recorded in the same area (8.1-8.37) by Nassar (1994) and in Suez Gulf (7.78-8.38) by Nassar (2000). However, the relatively higher $\mathrm{pH}$ values were recorded during the warm seasons in which the rise in temperature usually stimulates phytoplankton photosynthetic activity causing more consumption of carbon dioxide and the rise of $\mathrm{pH}$ (Abdallah et al., 1995a).

\section{3) Water salinity}

As shown in Table 1, the maximum value of salinity $(41.85$ $\%$ ) was recorded at station VI during summer. The minimum value of $40.9 \%$ was occurred at station IV during winter, as a result of dilution by effluents discharged from sewage treating company $A B B$. The results indicated that the salinity of the surface water reached its maximum during summer and early autumn and the minimum in winter. This may be attributed to evaporation of water by the elevation of temperature, as well as the entrance of high salinity water from Suez Canal into the bay (Morcos, 1970). However, evaporation is one of the controlling factors for salinity and consequently density, circulation and sea level variation (Maiyza, 1988).

\section{4) Dissolved Oxygen (DO)}

Dissolved oxygen is the best parameter to show the effect of pollution in the aquatic ecosystem unless it contains toxic constituents (Lester, 1975). The data indicated that DO varied between a maximum of $6.66,6.51 \mathrm{mg} \mathrm{O} \cdot \mathrm{L}^{-1}$ at the stations I and II, respectively during autumn and minimum values of $4.2,4.1 \mathrm{mg} \mathrm{O}_{2} \cdot \mathrm{L}^{-}$ ${ }^{\prime}$ at the stations V and VI, respectively during winter (Table 1). The slight increase of dissolved oxygen during autumn and spring was associated with highest flourishing of phytoplankton in these seasons (average of 15,376 and 15,676 unit. $\mathrm{L}^{-1}$, respectively). This high oxygen content indicates a good mixing in the water column (Girgis, 1980). However, the results indicated a strong positive correlation between phytoplankton counts and dissolved oxygen $(r=0.94)$. Such resuit agrees with that obtained by Abdallah et al. (1995b); Gharib (1998) and Nassar (2000), who stated that dense phytoplankton correlated with high oxygen concentration.

\section{5) Biological Oxygen Demand (BOD)}

The biological oxygen demand is defined as the amount of oxygen consumed by the respiration process in a limited volume of water and incubated in the dark at constant temperature $\left(20^{\circ} \mathrm{C}\right)$ for 
five days (APHA, 1989). The results showed that BOD varied between $4.61 \mathrm{mg} \mathrm{O} \cdot \mathrm{L}^{-1}$ at St. IV during winter and $0.95 \mathrm{mg} \mathrm{O} \cdot \mathrm{L}^{-1}$ during spring at St. VI, which is relatively far from the pollution sources. The high BOD values at St. IV may be due to direct effect of acute pollution by disposal of sewage wastes from Suez City. The low BOD level of St. VI proves its purity and this agrees with ANON (1975), who reported that a BOD of $1 \mathrm{ppm}$ is a characteristic of nearly pure water.

\section{6) Chemical oxygen demand (COD)}

Another way to assess the degree of sewage pollution in Suez Bay is to measure the organic matter present in water samples taken periodically under the same sampling conditions. The results in Table 1 indicate that maximum $\mathrm{COD}$ value of $2.78 \mathrm{mg} \mathrm{O} \cdot \mathrm{L}^{-1}$ occurred at St. IV during winter. Such value may be due to the effect of sewage effluents of Suez City. The minimum COD value of $0.56 \mathrm{mg} \mathrm{O} \mathrm{O}_{2} \mathrm{~L}^{-1}$ was recorded during spring at St. VI, which is virtually clean. The data revealed that BOD and COD values in Suez Bay showed a gradual increase southward, reaching their maximum value at St. IV, that lies in the vicinity of Suez City and receives its wastes.

\section{7) Nutrients}

\section{a) Ammonia}

Ammonia is biologically active compound present in most water as normal biological degradation product of organic nitrogen. It can be utilized directly as nutrients by several algal species and aquatic plants (UNESCO, 1988; Mahmoud, 1995 and Stolte and Riegman, 1995). The results in Table 1 showed that ammonia formed about $60.71 \%$ of the total inorganic nitrogen in Suez Bay with an annual average of $9.15 \mu \mathrm{mol} . \mathrm{L}^{-1}$. Ammonia contents were high at the relatively polluted stations IV and V specially in winter and summer seasons, during . which lowest phytoplankton standing crop was recorded. In waters directly polluted by sewage or substantially polluted by river discharge, the concentrations of ammonia are often higher than $20 \mu \mathrm{mol} . \mathrm{L}^{-1}$ as reported by UNESCO (1988). On the other hand, relativcly low values of ammonia were observed during the most productive seasons, autumn and spring (Table 3). Consequently, the resuits revealed a strong inverse correlation ( $\mathrm{r}=$ 0.96) between ammonia concentrations and phytoplankton standing crop. This finding agrees with the data reported by Abdallah $e t$ al. (1995b). However, it is clear that ammonia concentration was somewhat high at the northwestern coast of the bay and decreased at 
the eastern coast. This is almost due to the disposal of sewage and industrial effluents at the western and northwestern parts of the bay.

b) Nitrite

Regarding nitrite, the consideration of its concentrations in seawater is useful because of its intermediate oxidation state between ammonia and nitrate. But it has the highest toxicological significance of human health, if present in perceptible concentration in diets. Maximum nitrite concentration of $1.61 \mu \mathrm{mol} . \mathrm{L}^{-1}$ was recorded at St. $\mathrm{V}$ during winter (Table 1). Such value is in quite agreement with the presence of ammonia at the same station and during the same season. The minimum value of nitrite being $0.26 \mu \mathrm{mol} . \mathrm{L}^{-1}$ occurred at St. VI during autumn. In general, nitrite is not a stable end product, its absence or presence in such quantities might not be so peculiar. Sverdrup et al. (1949) reported a range of nitrite from 0.01 to 3.5 $\mu \mathrm{mol} . \mathrm{L}^{-1}$ in the sea. However, in the investigated area and during the low temperature season (winter), nitrite concentration showed the maximum value (average of $1.07 \mu \mathrm{mol} . \mathrm{L}^{-1}$ ). This may be attributed to nitrate reduction at low oxygen levels.

c) Nitrate

Nitrate is considered as the most stable and predominant inorganic nitrogen form in seawater. The results showed that nitrate content formed about $33.7 \%$ of the total inorganic nitrogen in Suez Bay. The maximum nitrate concentrations were 10.73 and 11.54 $\mu$ mol. $L^{-1}$ occurred at the stations IV and V, respectively during autumn, in which the high flourishing of phytoplankton was observed. The minimum nitrate value of $2.0 \mu \mathrm{mol} . \mathrm{L}^{-1}$ was recorded at St. VI during winter, when the lowest counts of phytoplankton. Generally, the increase in nitrate content of seawater is followed by an increase in both production and chlorophyll-a level (Saad and Fahmy, 1984). Hamed (1992) reported that surface nitrate concentration in Suez Bay varied between 18.0 and $0.43 \mu$ mol. $\mathrm{L}^{-1}$. However, the results indicated a significant positive correlation (r= 0.97 ) between dissolved nitrate and phytoplankton standing crop, which coincided with the data reported by Nassar (2000).

\section{d) Phosphate}

As presented in Table 1, the dissolved inorganic phosphate in Suez Bay fluctuated between a maximum of 1.78, $1.52 \mu \mathrm{mol} . \mathrm{L}^{-1}$ at the relatively polluted stations IV and $\mathrm{V}$, respectively during winter and a minimum of $0.27 \mu \mathrm{mol} . \mathrm{L}^{-1}$ at the unpolluted station VI during autumn. Hamed (1992) indicated that the average of phosphate concentration in the surface water of Suez Bay was $0.85 \mu \mathrm{mol} . \mathrm{L}^{-1}$. 
The dissolved phosphate values of 0.47 and $0.81 \mu \mathrm{mol}^{-1} \mathrm{~L}^{-1}$ were recorded in the Gulf of Suez and Suez Canal, respectively (Hamed, 1996). Stirn (1972) reported that the normal seawater contains dissolved phosphate in the range of $0.0-0.3 \mu \mathrm{mol} . \mathrm{L}^{-1}$, which is relatively coincided with the results of the present study at St. VI. Whereas, in the oceans, phosphate fluctuates between, 0.2 and 3.5 $\mu \mathrm{mol} . \mathrm{L}^{-1}$. In comparison with the Gulf of Aden and Red Sea, concentration of dissolved inorganic phosphate in the Suez Gulf is relatively low (Morcos, 1970). However, a significant inverse correlation coefficient $(\mathrm{r}=-0.74)$ was observed between dissolved phosphate and phytoplankton standing crop.

e) Nitrogen-phosphorus ratio (N:P)

The N:P ratio appeared to be an important ecological parameter because it gives account for dominance and succession of algal species and eutrophication (Smith, 1983). Riley and Skirrow (1967) showed that a relatively constant N:P ratio of 15:1 was found statistically on a world scale. Generally, the N:P ratio varies from one location to the other depending on the seasonal variability of quality and quantity of wastes discharged into the study area. In this connection, Chiaudani and Vighi (1978) reported that marine algae, in general, are $\mathrm{P}$-limited at $\mathrm{N}: \mathrm{P}$ ratio $>6$ and $\mathrm{N}$-limited at the ratio of $<4.5$, while in the range of 4.5-6, the two nutrients are near their optimal assimilative proportion. In the present study, the water of Suez Bay was generally P-limited, mainly due to the high load of nitrogenous compounds specially ammonia, that reached its highest values at the relatively polluted stations $I V$ and $V$. The annual average of $\mathrm{N}: \mathrm{P}$ ratio was 15.49 . In conclusion, the level of nutrient salts indicated that Suez Bay is in the eutrophic state according to the standard levels reported by Franco (1983).

\section{f) Silicate}

Regarding silicate content, the highest values of 4.4 and 4.66 $\mu$ mol. $\mathrm{L}^{-1}$ were found at the stations $\mathrm{V}$ and VI, respectively during winter, at which the diatoms showed their lowest numbers. On the other hand, the lowest silicate values of 1.21 and $1.3 \mu \mathrm{mol} . \mathrm{L}^{-1}$ were recorded at the stations $I$ and. II, respectively, during spring, which sustained the highest flourishing of diatoms as indicated in Table 3. However, the pronounced decrease in silicate content during autumn and spring may be due to the flourishing diatoms at that time. In accordance with the results of this study; Harding (1992), Gharib and Soliman (1998) and Nassar (2000) reported the depletion of silica was 
always associated with flourishing of diatom populations. Moreover, an inverse correlation between silicate and diatom population $(r=-$ 0.88 ) was recorded and this agrees with the findings reported by by Kobbia (1982); Harding (1992); Abdallah et al. (1995a); Gharib and Soliman (1998) and Nassar (2000).

\section{Phytoplankton standing crop}

\section{-Community composition and distribution}

Total of 80 species comprising 47 Bacillariophyceae, 19 Dinophyceae, 7 Cyanobacteria, 6 Chlorophyceae and one rarely form of Chrysophyceae (Table 4). Bacillariophyceae was the most dominant group forming about $76.68 \%$ by number to the total phytoplankton standing crop. Dinophyceae was recorded with moderate counts constituting about $20.94 \%$ of the total phytoplankton. Cyanobacteria and Chlorophyceae were observed with small counts forming about 1.92 and $0.35 \%$ of the total phytoplankton, respectively. On the other hand, Chrysophyceae was represented by only one species (Table 2 ).

The highest standing crop of phytoplankton was found at the stations, Port-Tawfik (I), EL-Zaitia (II) and AL-Kabanon (III) with average counts of $13,440,13,763$ and 12,389 unit. $\mathrm{L}^{-1}$, respectively. This may be attributed to the low fractions of petroleum hydrocarbons discharged from the oil refineries, El-Nasr and Suez petroleum companies. These oil fractions could be stimulating the standing crop of phytoplankton as previously recorded by Rinkevich and Loya (1983) and Nassar (1994). On the other hand, the relative low counts were found at the unpolluted station, Aiyoon Mousa (VI) with an average value of 7,007 unit. $L^{-1}$, although the highest diversity of species was observed at this station. However, some species are responsible for flourishing of phytoplankton at stations I, II and III namely, Nitzschia pungens var. atlantica, Asterionella japonica, Skeletonema costatum, Chaetoceros decipiens, Gyrosigma attenuatum and Chaetoceros curvisetus of diatoms, as well as Ceratium furca, C. trichoceros and C. fusus of dinoflagellates.

\section{- Seasonal distribution}

Spring followed by autumn (2002) were the most productive seasons when phytoplankton crop reached to 15,676 and 15,376 unit. $L^{-1}$, respectively (Table 3 ). This is due to the high population density of the diatoms, Nitzschia pungens var. atlantica and Chaetoceros decipiens during autumn, as well as the flourishing of Asterionella japonica, Skeletonema costatum and Gyrosigma attenuatum during spring season (Table 5). These results are 


\section{TO SOME WATER CHARACTERISTICS}

supported by those of Levanon-Spainer et al. (1979), Khalil et al. (1984), Khalil and Ibrahim (1987 and 1988) and Nassar (2000). They reported that the Red Sea exhibited a different and unique trend in which autumn represented the most productive season.

Judging from the previous study of Suez Bay (Nassar, 1994); about $71 \%$ of the recorded species in the present study were previously detected, whereas about 12 species of diatoms (Chaetoceros lorenzianus, $C$. peruvianus, C. coarctatus, Hemiaulus heibergii, Biddulphia mobiliensis, B. obtusa, Climacodium biconcavum, Coscinodiscus granii, Licmophora gracilis, Gramatophora marina, Thalassiothrix longissima and Fragillaria sp.); five species of dinoflagellates (Ceratium minutum, Peridinium divergens, Pyrophacus horologicum, Goniaulax minuta and Oxytoxum scolopax); two species of Cyanobacteria (Oscillatoria tenuis and Spirulina platensis) and four species of green algae (Scenedesmus bijuga, $S$. dimorphus, Staurastrum paradoxum and Stigoclonium sp.) could be considered as new records in Suez Bay in the present study. The fresh and brackish water species were observed in front of the sewage treating station (ABB), due to large quantities of fresh inland water discharged from the sewage treating company of Suez City. Generally, some of these records were previously reported in Suez Canal, Suez Gulf and Red Sea by Halim (1969), Dowidar (1976), Dowidar et al. (1978), Ibrahim (1988), El-Sherif and Ibrahim (1993), El-Sherif and Abo El-Ezz (2000) and Nassar (2000).

In conclusion, comparison of the present study with that recorded by Nassar (1994), the results indicated that the standing crop of phytoplankton showed sever drop and decreased from 106,861 unit. $L^{-1}$ (previous study) to 10,810 unit. $\mathrm{L}^{-1}$ (present study), while the total number of species is slightly increased from 76 species in the previous study to 80 species in the present study (Table 4). On the other hand, slight increase in the number of species of both bluegreen and green algae was observed, which attributed to the freshwater discharged from the sewage treating company (ABB) of Suez City.

\section{- Species diversity}

Results of diversity in Suez Bay sustained good variations of species as indicated by the averages of $3.36,2.58,3.13$ and 2.4 nats during winter, spring, summer and autumn, respectively. The highest diversity value of 3.61 nats was recorded at the unpolluted station, Aiyoon Mousa (VI) during winter. This could be attributed to the 
increased number of species ( 40 species), which reflects the absence of distinct dominance of any particular species, where the dominance at St. VI during winter was shared by several species. On the other hand, the lowest diversity appeared at the sewage treating station, ABB (IV) during autumn with 2.17 nats, where the more frequent diatom, Nitzschia pungens var. atlantica formed about $53 \%$ of the total phytoplankton at this station during autumn. However, the species diversity of phytoplankton declines markedly during the period of great change in the environmental factors and also may be due to the nutritional levels and their availability (Abdallah et al., 1992; El-Sherif, 1993; Zaghloul, 1994 and 1995; El-Sherif and Zaghloul, 1994; Gharib, 1998 and Nassar, 2000).

Furthermore, results revealed regional and seasonal inverse correlation between diversity and the standing crop of phytoplankton in the Suez Bay ( $r=-0.58$ and -0.97 , respectively) and it is regarded as a polluted habitat.

\section{REFERENCES}

Abdallah, R. R. ; Halim, Y. ; Gergis, W. L. and Assad, F. N. (1992). Phytoplankton diversity in the oligotrophic waters west of Alexandria (Egypt). Bull. Nat. Inst. Oceanogr.\& Fish., A.R.E., 18: 73-84.

Abdailah, R. R. ; Zaghloul, F. A. and Hussein, N. R. (1995a). A statistical modeling of phytoplankton eutrophication in the Eastern Harbour, Alexandria, Egypt. Bull. Nat. Inst. Oceanogr. \& Fish., A.R.E., 21(1): 125-146.

Abdallah, R. R. ; Zaghloul, F. A. ; Hassan, Y. A. and Moustafa, H. M. (1995b). Some water quality characteristics of El-Dekhella Harbour, Alexandria, Egypt. Bull. Nat. Inst. Oceanogr. \& Fish., A.R.E., 21(1): 85-102.

American public Health Association (APHA), (1989). Standard methods for the examination of water and wastewater, $17^{\text {th }}$ Ed., New York, 626 pp.

American public Health Association (APHA), (1995). Standard methods for the examination of water and wastewater, $19^{\text {th }}$ Ed., New York, 1015 pp. 
ANON, (1975). Environmental control and public health, water analysis, standards and treatment, Eyre and Spohiswoode Ltd., ECPH, 131 pp.

Behrendt, H. (1990). The chemical composition of phytoplankton and zooplankton in an eutrophic shallow lake. Arch. Hydrobiol., 118(2): 129-145.

Bold, H. C. and Wynne, M. J. (1978). Introduction to the algae, structure and reproduction. Prentice-Hall, Inc. Englewood Cliffs, U.S.A., 706 pp.

Bourrelly, P. (1968). Les algues d'eau douce, initiation a la systematique. Tom II: Les algues Jaunes et brunes, Chrysophycées, Phaeophycées, et Xanthophycées. Ed. N. Boubée and Cie, Paris, 438 pp.

Chiaudani, G. and Vighi, M. (1978). Methodologia standard disaggio algae per 10 studio dello acque marine quaderni dell Instituto di Ricerca Sulle acque, 29, $120 \mathrm{pp}$.

Cupp, E. E. (1943). Marine plankton diatoms of the west coast of North America. University of California Press, Berkely and Los Angeles, California, $238 \mathrm{pp}$.

Dowidar, N. M. (1976). The phytoplankton of the Suez Canal. Symp. East. Med. Sea. IBP/PM UNESCO. Acta Adriatica, 18(14): 241-255.

Dowidar, N. M. ; Raheem El-Din, S. A. and Aleem, A. A. (1978). Phytoplankton population in the region of Obhur (Jeddah, Saudi Arabia). Bull. Fac. Sci., K. A. Uni., Jeddah, 2: 271-292.

EL-Nayal, A. A. (1935). Egyptian freshwater algae. Bull. Fac. Sci. Cairo, (4), 106 pp.

El-Sherif, Z. M. (1993). Phytoplankton standing crop, diversity and statistical multispecies analysis in Lake Borollus, Egypt. Bull. Nat. Inst. Oceanogr. \& Fish., A.R.E., 19: 213-233. 
El-Sherif, Z. M. and Abo El-Ezz, S. (2000). Check list of plankton of the northern Red Sea. Pakistan J. Marine Science (in press).

El-Sherif, Z. M. and Ibrahim, A. M. (1993). Phytoplankton production, diversity and chlorophyll-a in Suez Canal, Egypt, Bull. Nat. Inst. Oceanogr. \& Fish., A.R.E., 19: 191-212.

El-Sherif, Z. M. and Zaghloul, F. A. (1994). Winter phytoplankton diversity in South-East Levantine Mediterranean Sea. The $4^{\text {th }}$ Conf. of Enviro. Prot. is A must, 487-502.

Franco, P. (1983). Fattori influent sulla productivita primaria dell Adriatico settentrionale proc. Int. Conf. Problems of the Adriatic Sea, Trieste, 155-174.

Ferguson Wood, E. J. (1968). Dinoflagellates of the Caribbean Sea and adjacent areas, Univ. of Miami press, Library of Congress Catalog card number, 68-9512, $141 \mathrm{pp}$.

Gharib, S. M. (1998). Phytoplankton community structure in Mex Bay, Alexandria, Egypt. J. Aquat. Biol. \& Fish, 2(3): 81-104.

Gharib, S. M. and Soliman, A. M. (1998). Some water characteristics and phyto-zooplankton relationship in Lake Edku (Egypt) and adjacent Sea. Bull. Fac. Sci. Alexandria Uni., i $(1,2): 25-44$.

Ghazzawi, F. M. (1939). A study of Suez Canal plankters. The Phytoplankton Hydrob. and Fish., Direct notes and memories, $24,83 \mathrm{pp}$.

Girgis, A. M. (1980). Investigation of level and effects of pollutants on saline lakes and littoral marine environments. Part II: Hydrography of Lake Qarun. Scientific Report, Acad. of Sci. Res. \& Tech., Inst. of Oceanogr. and Fish., 166 pp.

Halim, Y. (1969). Plankton of the Red Sea. Oceanogr. Mar. Biol. Ann. Rev., 7: 231-275.

Hamed, M. A. (1992). Seawater quality at the northern part of the Gulf of Suez and the nearby area of the Suez Canal. M. Sc. Thesis, Fac. of Science, Mansoura University. 
Hamed, M. A. (1996). Determination of some microelements in the aquatic ecosystem and their relation to the efficiency of aquatic life. Ph. D. Thesis, Fac. of Science, Mansoura University.

Harding, W. R. (1992). Zeekoevlei-Water chemistry and phytoplankton periodicity. Water SA, 18(4): 237-246.

Huber-Pestaluzzi, G. (1938). Das phytoplankton des Succwassers. I. Teile, Die Binnergewasser. Stuttgart, 342 pp.

Ibrahim, E. A. (1988). Observations on the distribution of phytoplankton in Foul Bay, Red Sea. Bull. Nat. Inst. Oceanogr. and Fish., A.R.E., 14(1): 91-103.

Khalil, A. N. and Ibrahim, A. M. M. (1987). Seasonal variations in the standing stock of phytoplankton near Jeddah, Red Sea. Bull. Nat. Inst. Oceanogr. \& Fish., A.R.E., 13(1): 219-228.

Khalil, A. N. and Ibrahim, A. M. M. (1988). A seasonal study of the surface phytoplankton of the Red Sea, North of Jeddah, Arab. Gulf. J. Sci. Res., 6(2): 189-204.

Khalil, A. N. ; Khafagi, A. K. and Ibrahim, A. M. (1984). Preliminary survey of micro-and macrophytes South of Jeddah, Red Sea. Proc. Symp. Coral Reef Environ. Red Sea. Jeddah, 555-576.

Kobbia, I. A. (1982). The standing crop and primary production of phytoplankton in Lake Brollus, Egypt. J. Bot., 25: 109-128.

Kobbia, I. A. ; Hassan, S. K. M. and Shoulkamy, M. A. (1990). Standing crop and distribution of phytoplankton in relation to nutritional status of a polluted drain at Minia province (Upper Egypt). Bull. Fac. of Sci., Assiut Univ., 19(2-D): 247 - 264.

Lester, W. F. (1975). Polluted River, River trant England, In: River Ecology, B. A. Whitton, Oxford, 725 pp.

Levanon-Spainer, I. ; Padan, E. and Resis, R. (1979). Primary production of a desert-enclosed Sea, the Gulf of Aqaba, Red Sea. Deep Sea Res., 26(6) : 673-685. 
Mahmoud, T. H. (1995). The effect of sewage discharge on water quality of the coast of Alexandria in spring and summer. J. Chemistry and Ecology, Malaysia, 11:255-268.

Maiyza, I. A. (1988). Evaporation of coastal water in the NW Red Sea. Bull. Inst. Oceanogr. and Fish., A.R.E., 14(1): 75-80.

Morcos, S. A. (1970). Physical and chemical oceanography of the Red Sea. Oceanogr. Mar. Biol. Annu. Rev., 8: 73-202.

Nassar, M. Z. (1994). Effect of oil pollution on the quantity and quality of the phytoplankton in Suez Bay of the Red Sea. M. Sc. Thesis. Bot. Depart., Fac. of Sci., Tanta Univ.

Nassar, M. Z. (2000). Ecophysiological studies on phytoplankton along the western coast of Suez Gulf. Ph. D. Thesis, Bot. Depart., Fac. of Sci., Tanta Univ.

Peragallo, H. and Peragallo, M. (1908). Diatomees marines de France et des Districts Maritimes Voisions, I-III (text and plates). Paris and Grez Sur-loing, 1-491.

Prescott, G. W. (1962). Algae of the western Great Lakes area. Brown, W. C., Dubuque (IOWA), 977 pp.

Riley, J. P. and Skirrow, G. (1967). Chemical Oceanography, Vol. I, Academic Press, London, Second Ed., 712 pp.

Rinkevich, B. and Loya, Y. (1983). Response of zooxanthellae photosynthesis to low concentrations of petroleum hydrocarbons. Bull. Nat. Inst. Oceanogr. \& Fish., A.R.E., 9: 109115.

Saad, M. A. H. and Fahmy, M. A. (1984). Chemico-physical characteristics of the coastal Red Sea waters north of Jeddah, Saudi Arabia. Proc. Symp. Coral Reef Environ. Red Sea, Jeddah, 109-128.

Shannon, G. E. and Weaver, W. (1963). The mathematical theory of communication. Univ. of Illinois Press, Urbana, $125 \mathrm{pp}$. 
Smith, V. H. (1983). Low nitrogen to phosphorus ratios favor dominance by blue-green algae in lake phytoplankton. Science, 221:669671 .

Stewart. K. D. and Mattox, K. R. (1975). Comparative cytology evolution and classification of green algae with some consideration of the other organisms with chlorophytes $a$ and $b$, Bot. Rev., 41: 104-135.

Stirn, J. (1972). Possibilities for constructive use of domestic sewage. In: Ruivo, M.(ed.) Mar. poll. and Sea life, London. Fishing News, 517-519.

Stolte, W. and Riegman, R. (1995). Effect of phytoplankton cell size on transient-state nitrate and ammonium uptake kinetics. Micro. Reading, U. K. Society for general microbiology, 141: 12211229.

Strickland, J. D. H. and Parsons, T. R. (1968). A practical Handbook of seawater analysis. Bull. Fish. Res. Ed. Canada, Ottawa, 167, $311 \mathrm{pp}$.

Sverdrup, H. U.; Johneon, M. W. and Fleming, R. H. F. (1949): The Oceans, their physics, chemistry and general biology, New York.

UNESCO, (1988). Eutrophication in the Mediterranean Sea receiving capacity and monitoring of long-term effects, Bologna, Italy, UNESCO Reports in Marine Science, (49), 195 pp.

Utermohl, H. (1936). Quantitative methoden zur untersuchung des nannoplankton. In: Adderheldens, Handbuch der Biolog. Arb. Methoden, $L X(2)$ : 1879-1937.

ZaghIoul, F. A. (1994). Impact of pollution on phytoplankton in a coastal marine environment. Bull. Nat. Inst. Oceanogr. \& Fish., A.R.E., 20(2): 205-221.

Zaghloul, F. A. (1995). Comparative study of phytoplankton production, composition and diversity index in the eutrophic Eastern Harbour of Alexandria, Egypt. Bull. High Inst. Pub. Health, 25 (3): $665-678$. 
Table 1: Water characteristics of Suez Bay during 2002-2003

\begin{tabular}{|c|c|c|c|c|c|c|c|c|c|c|c|c|}
\hline \multirow{2}{*}{$\begin{array}{l}\text { Season } \\
\text { Station }\end{array}$} & \multicolumn{6}{|c|}{ Spring (2002) } & \multicolumn{6}{|c|}{ Sunmer (2002) } \\
\hline & 戀 & 聯 & 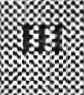 & 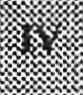 & 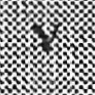 & 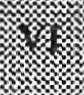 & & s. & 聯 & . & 3 & \\
\hline Temp. & 21.0 & 21.0 & 21.0 & 22.0 & 22.5 & 22.5 & 28.0 & 28.0 & 28.0 & 28.0 & 29.0 & 29.0 \\
\hline PH & 8.41 & 8.42 & 8.44 & 8.47 & 8.45 & 8.38 & 8.48 & 8.49 & 8.53 & 8.59 & 8.55 & 8.47 \\
\hline Salinity & 41.2 & 41.3 & 41.1 & 41.0 & 41.11 & 41.7 & 41.7 & 41.7 & 41.3 & 41.2 & 41.7 & 41.85 \\
\hline DO & 6.35 & 6.4 & 6.11 & 5.5 & 5.0 & 4.37 & 5.43 & 5.2 & 4.8 & 5.1 & 4.91 & 4.75 \\
\hline BOD & 2.26 & 2.31 & 2.64 & 3.27 & 3.08 & 0.95 & 2.54 & 2.86 & 3.21 & 4.0 & 3.26 & 1.58 \\
\hline COD & 0.88 & 1.1 & 1.43 & 2.31 & 1.92 & 0.56 & 1.2 & 1.36 & 1.68 & 2.56 & 2.08 & 0.88 \\
\hline $\mathrm{PO}_{4}$ & 0.73 & 0.86 & 0.97 & 1.34 & 1.1 & 0.47 & 0.9 & 0.96 & 1.10 & 1.25 & 1.00 & 0.50 \\
\hline $\mathrm{NO}_{3}$ & 8.76 & 8.91 & 6.98 & 4.91 & 3.76 & 2.93 & 6.20 & 5.83 & 3.96 & 3.28 & 4.51 & 2.66 \\
\hline $\mathrm{NO}_{2}$ & 0.31 & 0.4 & 0.66 & 0.92 & 1.2 & 0.19 & 0.84 & 0.9 & 1.08 & 1.17 & 1.27 & 0.45 \\
\hline $\mathrm{NH}_{4}$ & 5.08 & 4.94 & 7.23 & 10.6 & 11.8 & 2.0 & 5.93 & 6.29 & 8.43 & 18.0 & 19.76 & 2.81 \\
\hline $\mathrm{SiO}_{4}$ & 1.21 & 1.3 & 2.15 & 2.25 & 2.68 & 3.21 & 2.49 & 2.10 & 2.86 & 3.00 & 3.88 & 4.08 \\
\hline
\end{tabular}




\section{Table 1: Continued}

\begin{tabular}{|c|c|c|c|c|c|c|c|c|c|c|c|c|}
\hline Season & \multicolumn{6}{|c|}{ Autunun (2002) } & \multicolumn{6}{|c|}{ Winter (2003) } \\
\hline Station & i & m & $\ldots$ & - & 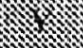 & X & & 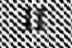 & II & 1 & ( & - \\
\hline Temp. & 23.5 & 23.5 & 24.0 & 24.0 & 24.0 & 24.0 & 17.0 & 17.0 & 17.0 & 17.5 & 17.5 & 18.0 \\
\hline $\mathbf{p H}$ & 8.46 & 8.47 & 8.5 & 8.53 & 8.52 & 8.4 & 8.35 & 8.39 & 8.40 & 8.49 & 8.41 & 8.31 \\
\hline Salinity & 41.5 & 41.6 & 41.3 & 41.1 & 41.5 & 41.75 & 41.0 & 41.1 & 41.0 & 40.9 & 41.1 & 41.45 \\
\hline DO & 6.66 & 6.51 & 6.3 & 5.4 & 5.55 & 5.79 & 5.4 & 5.15 & 5.30 & 4.90 & 4.20 & 4.10 \\
\hline BOD & 2.86 & 2.54 & 2.98 & 3.4 & 3.16 & 1.22 & 2.78 & 2.91 & 3.11 & 4.61 & 3.76 & 1.71 \\
\hline $\mathrm{COD}$ & 1.47 & 1.25 & 1.61 & 2.16 & 1.74 & 0.68 & 1.33 & 1.40 & 1.20 & 2.78 & 2.33 & 1.05 \\
\hline $\mathrm{PO}_{4}$ & 0.61 & 0.86 & 1.22 & 1.41 & 0.87 & 0.27 & 1.0 & 1.11 & 1.17 & 1.78 & 1.52 & 0.61 \\
\hline $\mathrm{NO}_{3}$ & 3.25 & 4.22 & 4.98 & 10.73 & 11.54 & 3.0 & 5.0 & 4.8 & 3.3 & 3.0 & 3.68 & 2.0 \\
\hline $\mathrm{NO}_{2}$ & 0.41 & 0.54 & 0.78 & 1.1 & 1.3 & 0.26 & 0.86 & 0.99 & 0.82 & 1.5 & 1.61 & 0.67 \\
\hline $\mathrm{NH}_{4}$ & 7.07 & 8.52 & 5.52 & 13.3 & 11.09 & 2.14 & 6.15 & 7.0 & 9.11 & 20.86 & 22.43 & 3.60 \\
\hline $\mathrm{SiO}_{4}$ & 1.45 & 1.54 & 2.08 & 2.33 & 2.6 & 3.87 & 3.00 & 2.25 & 3.21 & 3.66 & 4.40 & 4.66 \\
\hline
\end{tabular}

Note: Temp $=$ temperature $\rho \mathrm{C}) ; \quad D O=$ dissolved oxygen $\left(\mathrm{mgO}_{2} \cdot \mathrm{L}^{-1}\right)$; $B O D=$ biological oxygen demand $\left(m_{2} O_{2} \cdot L^{-1}\right) ; C O D=$ chemical oxygen demand $\left(m g O_{2} \cdot L^{-1}\right)$ and the nutrients, $\mathrm{PO}_{4}, \mathrm{NO}_{3}, \mathrm{NO}_{2}, \mathrm{NH}_{4} \& \mathrm{SiO}_{4}\left(\mu \mathrm{mol} \cdot \mathrm{L}^{-1}\right)$. 
Table 2: Annual average counts of different phytoplankton classes (unit. $\mathrm{L}^{-1}$ ) in Suez Bay during 2002-2003.

\begin{tabular}{|l|c|c|c|c|c|c|c|}
\hline Class & I & II & III & IV & V & VI & $\%$ \\
\hline Bacillariophyceae & 10.528 & 10.675 & 9.490 & 7.467 & 6.427 & 5.144 & 76.68 \\
Chrysoplyceae & 17 & 17 & 0.0 & 17 & 0.0 & 17 & 0.1 \\
Dinophyceae & 2.656 & 2.913 & 2.714 & 1.612 & 2.048 & 1.640 & 20.94 \\
Cyanobacteria & 239 & 158 & 149 & 310 & 186 & 206 & 1.92 \\
Chloroplycene & 0.0 & 0.0 & 36 & 193 & 0.0 & 0.0 & 0.35 \\
\hline Tolal & 13.440 & 13.763 & 12.389 & 9.599 & 8.661 & 7.007 & 100 \\
\hline
\end{tabular}

Table 3: Seasonal variations of different phytoplankton classes (unit. $\mathrm{L}^{-1}$ ) in Suez Bay (average of the six stations) during 2002-2003

\begin{tabular}{|l|c|c|c|c|c|}
\hline \multirow{2}{*}{ Season } & Spring & Summer & Autumn & Winter & \multirow{2}{*}{ Average } \\
\cline { 2 - 6 } & \multicolumn{3}{|c|}{2002} & 2003 & \\
\hline Bacillariophyceae & 11,952 & 2,938 & 14,034 & 4,231 & 8,289 \\
Chrysophyceae & 0.0 & 44 & 0.0 & 0.0 & 11 \\
Dinophyceae & 3,344 & 3,185 & 1,261 & 1,265 & 2,264 \\
Cyanobacteria & 287 & 204 & 70 & 271 & 208 \\
Chlorophyceae & 93 & 48 & 11 & 0.0 & 38 \\
\hline Total & 15,676 & 6,419 & 15,376 & 5,767 & 10,810 \\
\hline
\end{tabular}


Table 4: Comparison between phytoplankton production in Suez Bay before and after treating the sewage of Suez City by ABB Company

\begin{tabular}{|l|c|c|c|c|}
\hline \multirow{2}{*}{ Class } & \multicolumn{2}{|c|}{$\begin{array}{c}\text { Suez Bay, 1992 } \\
\text { Nassar, 1994) }\end{array}$} & \multicolumn{2}{|c|}{$\begin{array}{c}\text { Suez Bay', } \\
\text { Present study }\end{array}$} \\
\cline { 2 - 5 } & gemus & Species & Genus & Species \\
\hline Bacillariophyceae & 32 & 49 & 29 & 47 \\
Chrysophyceae & 1 & 1 & 1 & 1 \\
Dinophyceae & 11 & 18 & 11 & 19 \\
Cyanobacteria & 5 & 5 & 4 & 7 \\
Chlorophyceae & 3 & 3 & 4 & 6 \\
\hline Total & 52 & 76 & 49 & 80 \\
\hline Standing crop (unit.L ${ }^{-1}$ ) & \multicolumn{2}{|c|}{106,861} & & 10,810 \\
\hline
\end{tabular}


Table 5: List of the recorded species of phytoplankton in Suez Bay and their seasonal distribution (average of the six stations, unit. $L^{-1}$ ) during 2002-2003

\begin{tabular}{|c|c|c|c|c|c|}
\hline \multirow[t]{2}{*}{ Season } & spring & Summer & Autumn & \multirow{2}{*}{$\frac{\text { Winter }}{2003}$} & \multirow{2}{*}{ Average } \\
\hline & \multicolumn{3}{|c|}{2002} & & \\
\hline Bacillariophyceae & & & & & \\
\hline Nitzschia pungens var. atiantica Cleve & 370 & 85 & 5.600 & 303 & 1,590 \\
\hline N. longissima Ehr. & 162 & 126 & 106 & 130 & 131 \\
\hline N. signa Kutz. & 222 & 89 & 82 & 102 & 124 \\
\hline Asterionella japonica Cleve & 4,797 & 134 & 579 & 150 & 1,415 \\
\hline Skeletonema costatum (Grev.) Cleve & 2,475 & 39 & 316 & 267 & 774 \\
\hline Chaetoceros decipiens Cleve & 0.0 & 75 & 1.925 & 480 & 620 \\
\hline C.currisctus Cleve & 102 & 78 & 1.675 & 124 & 495 \\
\hline C. contissimus Gran. & 0.0 & 52 & 176 & 0.0 & 57 \\
\hline C lorenzianus Grun. & 0.0 & 0.0 & 51 & 0.0 & 13 \\
\hline Cperwiames Brightwell & 21 & 0.0 & 11 & 0.0 & 8 \\
\hline C. coarctatus Lauder & 13 & 0.0 & 0.0 & 0.0 & 3 \\
\hline Gyrosigma attennatmm Ehr. & 1.494 & 357 & 137 & 195 & 546 \\
\hline G. balticum Her. & 35 & 0.0 & 0.0 & 0.0 & 9 \\
\hline Rhizosolenia alata l. gracillima (Cleve) & 614 & 153 & 727 & 188 & 420 \\
\hline R. alata f indica H. Peragallo & 171 & 0.0 & 72 & 73 & 79 \\
\hline R. imbricata var. shrubsolei (Cleve) & 119 & 0.0 & 137 & 69 & 81 \\
\hline R. calcaravis M. Schultze & 0.0 & 79 & 87 & 71 & 59 \\
\hline R. stolterfothii H. Peragallo & 121 & 0.0 & 115 & 0.0 & 59 \\
\hline Leplocylindins danicus Cleve & 149 & 77 & 274 & 977 & 369 \\
\hline Hemianlus heibergï Cleve & 47 & 91 & 724 & 123 & 246 \\
\hline Surivella ovata Kutz & 101 & 339 & 124 & 118 & 170 \\
\hline S. robusta Ehr. & 9 & 0.0 & 11 & 0.0 & 5 \\
\hline Biddulphia mobiliensis Bail. & 61 & 205 & 183 & 138 & 147 \\
\hline B. obttsa Kutz & 0.0 & 46 & 0.0 & 0.0 & 12 \\
\hline B. sp. & 11 & 33 & 24 & 0.0 & 17 \\
\hline
\end{tabular}


Table 5: Continued

\begin{tabular}{|c|c|c|c|c|c|}
\hline Grimardia flaccida Hi Peragallo & 159 & 116 & 180 & 132 & 147 \\
\hline Cumpylodiscus noricus var, hibemica Ehr. & 106 & 87 & 76 & 71 & 85 \\
\hline Amphora marina Smith & 72 & 80 & 80 & 100 & 83 \\
\hline Amphiprora paludosa W. Smith & 117 & 68 & 31 & 72 & 72 \\
\hline 4. alara Kutz & 0.0 & 0.0 & 45 & 0.0 & 11 \\
\hline Cerataulina bergonii H. Peragallo & 0.0 & 46 & 150 & 69 & 69 \\
\hline Navicula gracilis Cleve & 57 & 68 & 71 & 76 & 68 \\
\hline Melosira sulcata (Ehr.) Kutz & 32 & 80 & 69 & 69 & 52 \\
\hline Climacodium biconcavum Cleve & 132 & 24 & 21 & 67 & 61 \\
\hline Coscinodiscus radiatus Ehr. & 0.0 & 154 & 11 & 0.0 & 41 \\
\hline C. granii Gough & 24 & 0.0 & 47 & 0.0 & 18 \\
\hline C. centralis Her. & 13 & 0.0 & 11 & 0.0 & 6 \\
\hline Lauderia borealis Gran & 98 & 0.0 & 39 & 0.0 & .34 \\
\hline Licnophora gracilis (Ehr.) Grunoiv & 0.0 & 22 & 0.0 & 67 & 22 \\
\hline Thalossionena nitzschioides Gran. & 0.0 & 54 & 13 & 0.0 & 17 \\
\hline Diploneis imentupta (Kutz) Cleve & 0.0 & 22 & 22 & 0.0 & 11 \\
\hline Symedra crystallina Lyngb. & 37 & 0.0 & 0.0 & 0.0 & 9 \\
\hline Climacosphenia moniligera Ehr. & 0.0 & 24 & 0.0 & 0.0 & 6 \\
\hline Gramatophora marina (Lyngb.) Kutz & 0.0 & 24 & 0.0 & 0.0 & 6 \\
\hline Thalassiothix longissima Cleve and Grun. & 0.0 & 11 & 11 & 0.0 & 6 \\
\hline Fragillaria sp. & 11 & 0.0 & 0.0 & 0.0 & 3 \\
\hline Striatella unipunctata Lyngb. & 0.0 & 0.0 & 11 & 0.0 & 3 \\
\hline \multicolumn{6}{|l|}{ Dinophycene } \\
\hline Ceratium fusus Ehr. & 129 & 1,616 & 78 & 88 & 478 \\
\hline C. trichoceros (Ehr.) Kofoid & 1,261 & 179 & 84 & 118 & 411 \\
\hline C. furca Ehr. & 985 & 161 & 85 & 159 & 347 \\
\hline C. massiliense (Gourtet) Jorgensen & 364 & 0.0 & 0.0 & 105 & 117 \\
\hline C. eguptiacum Halim & 13 & 74 & 225 & 107 & 104 \\
\hline C. tripos (O. M. Muller) Nitzsch. & 124 & 80 & 78 & 105 & 97 \\
\hline C. minutum Jorgensen & 0.0 & 0.0 & 11 & 0.0 & 3 \\
\hline Peridininm cerasus Paulsen & 101 & 120 & 144 & 127 & 123 \\
\hline P. depressum Bailey & 91 & 110 & 111 & 97 & 102 \\
\hline P. divergens Ehr. & 66 & 84 & 105 & 70 & 81 \\
\hline
\end{tabular}


Table 5: Continued

\begin{tabular}{|c|c|c|c|c|c|}
\hline Dimoplivsis caudala Savielle-Kent & 111 & lyy & 1118 & 71 & 122 \\
\hline Extmiaella marina Ostenteld & 77 & 118 & 91 & 80 & 91 \\
\hline Prorocentmim micans Ehr. & 0.0 & 111 & 71 & $6 y$ & 6.3 \\
\hline Diplopsalis ronnda (Lebour) Wood & 0.0 & 82 & 37 & 69 & 47 \\
\hline Phalacroma rapa Siein & 0.0 & 121 & 22 & 0.0 & 36 \\
\hline Pyrophacus horologicum Stein & 0.0 & 108 & 11 & 0.0 & 30 \\
\hline Goniaulax minuta Kotoid and Michener & 22 & 0.0 & 0.0 & 0.0 & 5 \\
\hline Oxytoxtm scolopax Stein & 0.0 & 11 & 0.0 & 0.0 & 3 \\
\hline Parahistoneis acula Bohm & 0.0 & 11 & 0.0 & 0.0 & 3 \\
\hline \multicolumn{6}{|l|}{ Cyanobacteria } \\
\hline Uscillatoria erythraenm Drouet & 172 & 35 & 0.0 & 200 & 102 \\
\hline O. temis Agardh & 54 & 95 & 0.0 & 0.0 & 37 \\
\hline O. sp. & 0.0 & .33 & 37 & 71 & 35 \\
\hline Spindina platensis Nordst. & 13 & $4 i$ & $1]$ & 0.0 & 16 \\
\hline S. major $\mathrm{KG}$. & 24 & 0.11 & 11 & 0.0 & 9 \\
\hline Merismopedia punctata Smith & 24 & 0.0 & 0.0 & 0.0 & 6 \\
\hline Lingbya majuscula Harvey & 0.0 & 0.0 & 11 & 0.0 & 3 \\
\hline \multicolumn{6}{|l|}{ Chlorophyceae } \\
\hline Scenedesmus quadricanda Breb. & 58 & 13 & 0.0 & 0.0 & 18 \\
\hline S. bijiga Turp. & 35 & 0.0 & 0.0 & 0.0 & 8 \\
\hline S. dimorphins Tarp. & 0.0 & 11 & 0.0 & 0.0 & 3 \\
\hline Pediastrum clathatum Lemun. & 0.0 & 13 & 0.0 & 0.0 & 3 \\
\hline Stamasmam paradoxam Menegl. & 0.0 & 11 & 0.0 & 0.0 & 3 \\
\hline Srigocloninm sp. & 0.0 & 0.0 & 11 & 0.0 & 3 \\
\hline \multicolumn{6}{|l|}{ Chrysophyceac } \\
\hline Dictocha fibula Ehr. & 0.0 & 44 & 0.0 & 0.0 & 11 \\
\hline Total standing crop (unit. $\mathrm{L}^{-1}$ ) & 15,676 & 6,419 & 15,376 & 5,767 & 10,810 \\
\hline
\end{tabular}




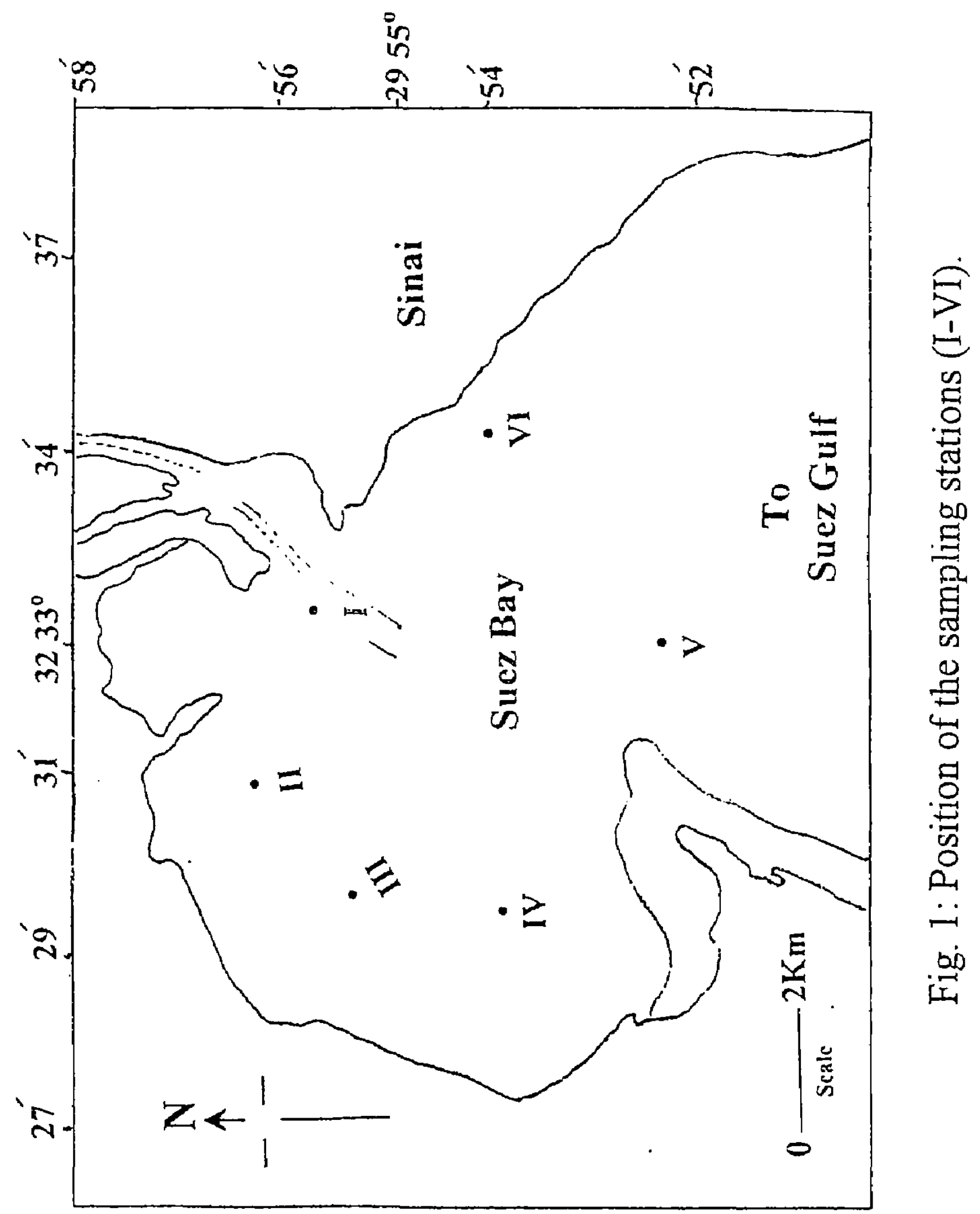

